ISSN 1392-3196 / e-ISSN 2335-8947

Zemdirbyste-Agriculture, vol. 102, No. 2 (2015), p. 201-208

DOI $10.13080 /$ z-a.2015.102.026

\title{
Amelioration of an open soilless cultivation system for microgardening spinach (Spinacia oleracea L.)
}

\author{
Shaghef EJAZ ${ }^{1,2}$, Karoline Maria JEZIK ${ }^{1}$, Werner STUMPF ${ }^{1}$, Christian GOSCH ${ }^{3}$, \\ Heidi HALBWIRTH ${ }^{3}$, Karl STICH ${ }^{3}$ \\ ${ }^{1}$ University of Natural Resources and Life Sciences \\ A-1180 Vienna, Austria \\ E-mail: shaghef@gmail.com \\ ${ }^{2}$ Bahauddin Zakariya University \\ 60800 Multan, Pakistan \\ ${ }^{3}$ Institute of Chemical Engineering, University of Technology \\ A-1060 Vienna, Austria
}

\begin{abstract}
The objective of this study was to develop an open soilless culture system with high water and nutrient use efficiency, and low emission in the environs for microgardening high quality spinach. For this purpose, spinach (Spinacia oleracea L.) was grown in containers with soilless media supplemented with organic and inorganic nutritional sources. The experiment was laid out in a complete randomized design with four replications. Seven growing media were assessed: peat moss, peat moss combined with 150,200 and $250 \mathrm{ppm}$ ammonium nitrate $\left(\mathrm{NH}_{4} \mathrm{NO}_{3}\right)$, and peat moss amended with compost having nitrogen equivalent to the mentioned $\mathrm{NH}_{4} \mathrm{NO}_{3}$ concentrations. Scheduled and quantified irrigation was provided with a sprinkler system to conserve water and minimize emission into the environment. Salt accumulation and $\mathrm{pH}$ of media was monitored throughout growing period. Spinach leaves were analyzed for total soluble solids, titratable acidity, ripening index, total nitrogen, total organic carbon, carbon to nitrogen ratio, fresh biomass, dry biomass, dry matter ( $\mathrm{mg} \mathrm{g}^{-1}$ fresh biomass), leaf moisture contents, nitrate content, colorimetric traits (lightness, chromacity and hue angle), ascorbic acid, total flavonols and anthocyanins and antioxidant capacity. Among all media, combinations of peat moss with $\mathrm{NH}_{4} \mathrm{NO}_{3}$ resulted in less nitrate, more organic carbon and dry matter ( $\mathrm{mg} \mathrm{g}^{-1}$ fresh biomass), higher total soluble solid contents and ripening index of the plants. A higher flavonoid content and higher antioxidant capacity were also observed in plants grown in these combinations. Further, these media accumulated less salt and maintained optimum $\mathrm{pH}$ level for spinach growth.
\end{abstract}

Key words: agro-pollutant, city farming, soilless culture, spinach, sphagnum peat moss.

\section{Introduction}

By 2050, the world's population is likely to reach nine billion that will result in an increased demand for food and considering the effects of climate change, the challenge to feed the population will be a chimera. During the past few decades, the request for proliferated food production to meet these demands has intensified the use of fertilizers that are contaminating the soil and underground water. Consequently, numerous health issues in humans and animals have surfaced especially due to the development of modern diagnostic techniques. Hence, regulations about reducing the emissions of nutrients and pesticides to soil and groundwater have been adopted in Europe and other developed countries (Van Os et al., 2012). Besides agro-pollutants, human health is at risk in areas where soil with poor texture, high pathogen infestation and unsuitable rhizosphere are constraints in good quality vegetable production.
On commercial scale, to counter these problems, soilless cultural techniques are the established alternative production systems. Soilless substrates have been shown to be beneficial in fruit, vegetable and ornamental crop production. Addition of compost to root media increases the antioxidant activity of spinach and Chinese cabbage (Ren et al., 2001). Compost enhances antioxidant activity, leaf nitrate reductase activity and chlorophyll content of well-fertilized strawberries. In addition, use of compost increases levels of organic acids (malic and citric acid), sugars (fructose, glucose and total sugars), soluble solids content and titratable acids content in strawberry fruit (Wang, Lin, 2002). Similarly, lettuce plants harvested from perlite or pumice culture had a higher titratable acidity, total nitrogen, phosphorus and potassium content than the plants grown on the soil culture (Siomos et al., 2001). Many researchers have observed higher sugar, 
soluble solids, vitamins and carotenoids content in tomatoes grown in soilless culture systems compared to soil (Gruda, 2009). However, most of the soilless techniques are not feasible for the microgarden system, where small areas such as balconies, backyards and small gardens can be utilized to grow herbs, vegetables and flowers for self-supplying to some extent that ensure access of nutritional diet to the people. Microgardens provide simple, low-budget and easy to manage soilless culture technology to urban or resources-poor rural families especially in developing countries (Orsini et al., 2013). Therefore, microgarden system based on soilless technology could increase the domestic availability of healthy food and may be practiced at sub-optimal climatic and soil conditions by efficiently managing the nutrients supply.

Closed soilless system is zero emission cultural techniques but their high installation cost and sophisticated running and maintenance make them unsuitable for microgardening. On the other hand, open soilless systems are commonly used for vegetable and ornamental crops, as their management is simple but high emission of water and nutrients causes the contamination of soil and underground water and also increases the running costs. Moreover, the pollution due to microgardens near the living places could be unsafe for the residents in nearby areas. Therefore, a modified open soilless culture technique based on low emission system should be developed to cultivate green leafy vegetables. As nitrogen is the most important limiting nutrient especially for the production of green leafy vegetables and has to be applied generously, the emission of nitrogen containing compounds becomes a serious environmental problem. To solve these issues, soilless technologies such as bag, container or vertical cultures could be modified to cultivate green leafy vegetables. Containers such as pots have certain benefits for microgardeners that include low cost, easy availability, portability during adverse weather condition, easy storage when no crop is being grown and utilizing the water and nutrient resources efficiently, hence, preventing the soil and water contamination.

Nitrogen being the most important nutrient for the production of green leafy vegetables if excessively applied in microgardens, costs more and leads to the bioaccumulation of nitrate in spinach that may be hazardous. Therefore, an on-field trial was set to optimize the quantity and source of nitrogen and to develop a low emission open soilless system for the pot cultivation of hazard free good quality spinach at microgarden.

\section{Material and methods}

A low emission soilless pot technique was developed for the cultivation of spinach during the year 2011 at the University of Natural Resources and Life Sciences, Vienna, Austria. For this purpose, pots with 30 $\mathrm{cm}$ diameter and 7.5 litres volume were used. Sphagnum peat moss served as the basic growing medium, whereas either compost or ammonium nitrate $\left(\mathrm{NH}_{4} \mathrm{NO}_{3}\right)$ was supplied as organic and inorganic sources of nitrogen, respectively. A slightly decomposed peat moss was supplied by Floragard Vertriebs GmbH (Germany) and had the following characteristics: $\mathrm{pH} 5.5$ to 6.0 , electrical conductivity (EC) 0.2 to $0.5 \mathrm{dS} \mathrm{m}^{-1}$, redox potential 260 to $265 \mathrm{mV}$, NPK fertilizer (18-10-20) $0.8 \mathrm{~kg} \mathrm{~m}^{-3}$. The compost had the following characteristics: $\mathrm{pH} 7.5$ to 7.75, EC 0.5 to $0.6 \mathrm{dS} \mathrm{m} \mathrm{m}^{-1}$, redox potential 190 to 195 $\mathrm{mV}$, carbon to nitrogen ratio $(\mathrm{C}: \mathrm{N})$ of $17: 1$. Aqueous $\mathrm{NH}_{4} \mathrm{NO}_{3}(33 \% \mathrm{~N})$ was used as an inorganic source of nitrogen. The experiment was laid out in a completely randomized design with seven treatments replicated four times. Sphagnum peat moss was used as the only growing medium for the pots where $\mathrm{NH}_{4} \mathrm{NO}_{3}$ had to be the primary source of nitrogen. Three concentrations of $\mathrm{N}(150,200$ and $250 \mathrm{ppm}$ ) were supplied as $500 \mathrm{ml}$ of $\mathrm{NH}_{4} \mathrm{NO}_{3}$ solutions twice a week to check the nutrient leaching and maintain a steady nutrient concentration in the root zone. Amount of compost was adjusted to nitrogen equivalent of $\mathrm{NH}_{4} \mathrm{NO}_{3}$ concentrations. Control treatment was not supplied with either $\mathrm{NH}_{4} \mathrm{NO}_{3}$ or compost. The treatment combinations are presented in Table 1.

Table 1. Various combinations of the growing medium and nitrogen sources

\begin{tabular}{cc}
\hline Labels & Treatments \\
\hline Peat & peat moss \\
AmN150 & peat moss $+\mathrm{NH}_{4} \mathrm{NO}_{3} 150 \mathrm{ppm}$ \\
AmN200 & peat moss $+\mathrm{NH}_{4} \mathrm{NO}_{3} 200 \mathrm{ppm}$ \\
AmN250 & peat moss $+\mathrm{NH}_{4} \mathrm{NO}_{3} 250 \mathrm{ppm}$ \\
CompN150 & peat moss + compost equivalent to $150 \mathrm{ppm} \mathrm{N}$ \\
CompN200 & peat moss + compost equivalent to $200 \mathrm{ppm} \mathrm{N}$ \\
CompN250 & peat moss + compost equivalent to $250 \mathrm{ppm} \mathrm{N}$ \\
\hline
\end{tabular}

Seeds of spinach (Spinacia oleracea L.) cv. 'Metador' were sown directly in pots. After one week of germination, plants were thinned to three per pot. To minimize the nutrient emission from the pots, sprinkler system was used to daily irrigate the plants till the media was wet. Moreover, three weeks after sowing, all pots were fertigated with $\mathrm{P}$ and $\mathrm{K}$ and at the same time, the fertigation with $\mathrm{NH}_{4} \mathrm{NO}_{3}$ to the selected pots started. Spinach leaves were harvested at physiological maturity when they were ready to be consumed as food and analyzed for their quality for human consumption.

Salinity and acidity of the media. Aqueous extracts of the media were obtained by $1: 1.5$ dilution method to monitor salt accumulation and $\mathrm{pH}$ of the media. EC and $\mathrm{pH}$ of the media were observed at sowing time, six weeks after sowing and at harvest time.

Growth and physiological measurements. At harvest stage, leaves of the spinach plants were analyzed for their colorimetric properties using tristimulus colorimeter Chroma Meter CR-400 ("Minolta", Japan). The CIELab scale uses the coordinates $\mathrm{L}^{*}, \mathrm{a}^{*}, \mathrm{~b}^{*}$ and determine chromacity $\left(\mathrm{C}^{*}\right)$ and hue angle $\left(\mathrm{H}^{\circ}\right)$ that has been successfully used for the colorimetric evaluation 
of leaf (León et al., 2007), fruit peel and pulp (Crisosto et al., 2007; Liang et al., 2011), vegetable peel (Gajewski et al., 2008) and flower (Osmani et al., 2009). The L* value indicates the colour appearance parameter of lightness or luminance and ranges from $100=$ the perfect white colour to $0=$ black. Hue angle $\left(\mathrm{H}^{\circ}\right)$ like SPAD reading, gives a rapid and non-destructive estimate of leaf chlorophyll content (León et al., 2007). $\mathrm{C}^{*}$ and $\mathrm{H}^{\circ}$ values were derived as suggested by Liang et al. (2011). After harvest, fresh biomass $\left(\mathrm{F}_{\mathrm{b}}\right)$, dry biomass $\left(\mathrm{D}_{\mathrm{b}}\right)$, dry matter $\left(\mathrm{D}_{\mathrm{m}}\right) \mathrm{mg} \mathrm{g}^{-1}$ fresh biomass and leaf moisture content (LMC) were evaluated.

For the determination of total soluble solids (TSS), titratable acidity (TA), ripening index, ascorbic acid (AA) and nitrate $\left(\mathrm{NO}_{3}\right)$ content of the leaves, leaf extract was prepared by blending fresh leaves and differentially centrifuging the slurry for five minutes at $1000 \mathrm{rpm}$. The supernatant was clarified with $10-20 \mu \mathrm{m}$ cellulose filter papers (VWR, France) and the filtrate was used for the determinations. TSS content was analyzed with a refractometer and presented as ${ }^{\circ}$ Brix value (Wang et al., 2007; Tabatabaei et al., 2008). Potentiometric titration of the leaf extract was carried out against $0.1 \mathrm{~N}$ $\mathrm{NaOH}$ up to $\mathrm{pH} 8.2$ for determining the TA as \% oxalic acid per $100 \mathrm{ml}$ of spinach leaf extract (Ergun, Jezik, 2011; Mahmood et al., 2012). Ripening index was calculated by the ratio between TSS and TA. Ascorbic acid content was determined as described by Ruck (1961). Extraction was carried out with $0.4 \%$ oxalic acid and the aliquot was titrated against 2,6-dichlorophenolindophenol dye until a faint pink colour appeared. Ascorbic acid was used as standard and the results were expressed as mg ascorbic acid per $100 \mathrm{ml}$ of leaf extract. Analysis of $\mathrm{NO}_{3}$ was performed by remission photometry method as described by Schmidhalter (2005). A digital reflectometer Reflectoquant RQflex plus ("Merck", Germany) was utilized for this purpose and content were expressed as $\mathrm{mg} \mathrm{NO}$ per litre of leaf extract.

Total nitrogen $(\mathrm{TN})$ and total organic carbon (TOC) were evaluated with an elemental analyzer CNS ("Elementar", Germany). Leaves were dried at $80^{\circ} \mathrm{C}$ for 72 hours and then ground to powder using a ball mill. TN $\left(\mathrm{mg} \mathrm{g}^{-1} \mathrm{D}_{\mathrm{b}}\right)$ and TOC $\left(\mathrm{mg} \mathrm{g}^{-1} \mathrm{D}_{\mathrm{b}}\right)$ were determined and $\mathrm{C}: \mathrm{N}$ ratio was calculated. Trolox equivalent antioxidant capacity (TEAC) of methanolic plant extracts was determined according to the DPPH method (BrandWilliams et al., 1995) with slight modifications. TEAC values were derived from the standard regression curve and $\mathrm{EC}_{50}$ values of Trolox and plant samples were calculated. $\mathrm{EC}_{50}$ values of plant samples were compared with reference to Trolox and the results were expressed in $\mu \mathrm{M} \mathrm{TE} \mathrm{g}^{-1} \mathrm{~F}_{\mathrm{b}}$.

Total flanonols and anthocyanins were extracted from the homogenized plant material with $2 \%(\mathrm{v} / \mathrm{v}) \mathrm{HCl} /$ methanol solution. Subsequently, the $\mathrm{HCl} /$ methanol solution was separated from tissue debris and centrifuged at $14.000 \mathrm{rpm}$ for three minutes. Duplicate determination was carried out by adding $140 \mu \mathrm{l}$ of the supernatant to $860 \mu \mathrm{HCl} /$ methanol solution. Using $\mathrm{HCl} /$ methanol as a blank, absorbance of the acidified dilute extract was measured at $360 \mathrm{~nm}$ for flavonols and at $520 \mathrm{~nm}$ for anthocyanins. Results were expressed as quercetinequivalents for flavonols and pelargonidin-equivalents for anthocyanins.

Statistical analysis. Using the software IBM SPSS (version 19), analysis of variance (ANOVA) was carried out and the main effects were tested using general linear model (GLM) procedure. The treatment means were separated by Duncan's multiple range test at $\alpha=5 \%$ and the correlations between the variables were explored using Pearson's correlation coefficient.

\section{Results}

Accumulation of salts and $\mathrm{pH}$ in the growing medium at harvest indicates nutrient uptake by a plant, salt retention capacity of the medium and therefore the reusability of the medium. Although at sowing time, higher EC values $\left(\approx 1.7 \mathrm{mS} \mathrm{cm}^{-2}\right)$ were observed for compost amended media compared to EC $1.15 \mathrm{mS} \mathrm{cm}^{-2}$ for other media, this gap between EC values almost diminished at harvest (Fig. 1).

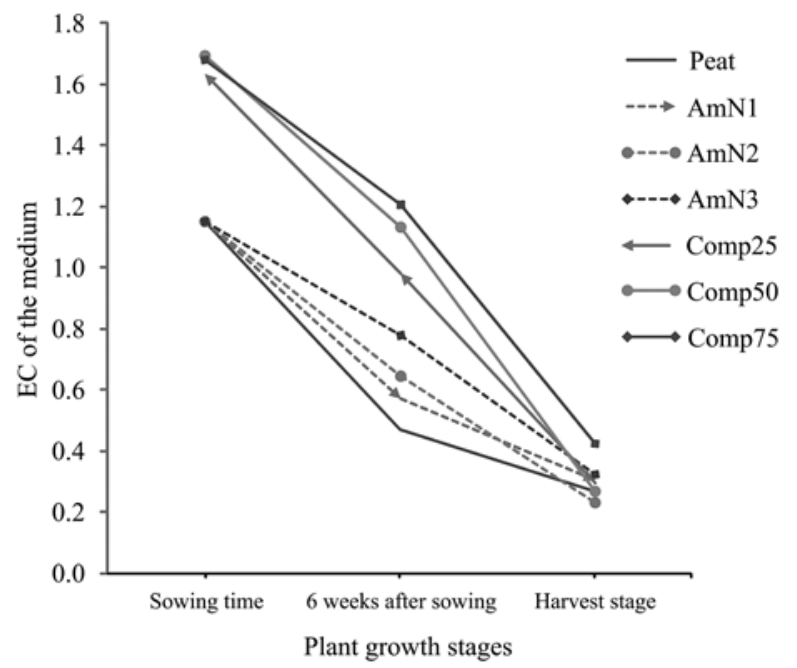

Figure 1. Electrical conductivity (EC) of the media monitored at different stages of spinach cultivation as affected by peat moss and its combination with compost and ammonium nitrate $\left(\mathrm{NH}_{4} \mathrm{NO}_{3}\right)$ fertigation

Compost amended media had higher $\mathrm{pH}(\approx 7)$ than the rest of the media $(\mathrm{pH}=5.6)$ but unlike $\mathrm{EC}$, this difference lasted till the harvest (Fig. 2).

Plants grown in peat moss showed the lowest $\mathrm{NO}_{3}$ content in their leaves, whereas adding compost in peat also increased the $\mathrm{NO}_{3}$, reaching at the highest level in CompN250 (Table 2). On the contrary, $\mathrm{NH}_{4} \mathrm{NO}_{3}$ fertigated plants assimilated the highest $\mathrm{TN}$ and peat treated plants the lowest. TOC was highest in plants grown with $\mathrm{AmN} 150$ and peat. The addition of $\mathrm{NH}_{4} \mathrm{NO}_{3}$ led to a decrease in TOC, whereas addition of compost led to the lowest TOC. Spinach growing in organic media without $\mathrm{NH}_{4} \mathrm{NO}_{3}$ showed a significantly higher $\mathrm{C}: \mathrm{N}$ ratio. Spinach cultivated in peat, AmN150 and AmN250 produced the highest TSS content. The compost amended media led to 


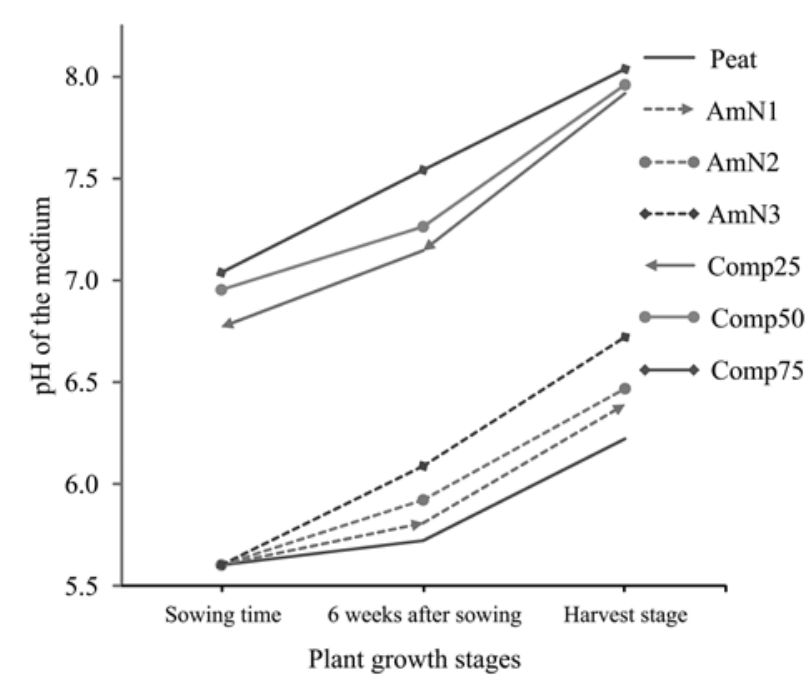

Figure 2. $\mathrm{pH}$ of the media monitored at different stages of spinach cultivation as affected by peat moss and its combination with compost and ammonium nitrate $\left(\mathrm{NH}_{4} \mathrm{NO}_{3}\right)$ fertigation a relatively lower TSS. As for titratable acidity, no effect of the treatments was observed. However, AmN150 and peat resulted in the highest ripening indices and CompN150 the lowest. In general, the compost amended media produced lower ripening indices.

Plants grown in compost amended media had significantly higher $\mathrm{L}^{*}$ and $\mathrm{C}^{*}$ values. No effect of various levels of either compost or $\mathrm{NH}_{4} \mathrm{NO}_{3}$ was observed. On the contrary, media amended with peat and $\mathrm{NH}_{4} \mathrm{NO}_{3}$ showed higher $\mathrm{H}^{\circ}$ values than compost. Levels of compost and $\mathrm{NH}_{4} \mathrm{NO}_{3}$ had no effect on $\mathrm{L}^{*}, \mathrm{C}^{*}$ and $\mathrm{H}^{\circ}$ tristimulus values (Table 3 ). Ascorbic acid content was not affected by any of the treatments. The plants grown in peat accumulated $100 \%$ or higher flavonols than composted plants and similarly, the plants gown in $\mathrm{NH}_{4} \mathrm{NO}_{3}$ supplemented media accumulated $77 \%$ or higher flavonols than those grown in compost. Increasing the level of $\mathrm{NH}_{4} \mathrm{NO}_{3}$ reduced the flavonols. Anthocyanins content was not detected in spinach grown in any of the media (data not shown). Plants grown in peat medium

Table 2. Nitrate $\left(\mathrm{NO}_{3}\right)$ content, total nitrogen (TN), total organic carbon (TOC), carbon to nitrogen ratio (C:N), total soluble solids (TSS), titratable acidity (TA) and ripening index as affected by different media

\begin{tabular}{cccccccc}
\hline Treatments & $\begin{array}{c}\mathrm{NO}_{3} \\
\mathrm{mg} \mathrm{L}^{-1}\end{array}$ & $\begin{array}{c}\mathrm{TN} \\
\mathrm{mg} \mathrm{g}^{-1} \mathrm{D}_{\mathrm{b}}\end{array}$ & $\begin{array}{c}\mathrm{TOC} \\
\mathrm{mg} \mathrm{g}^{-1} \mathrm{D}_{\mathrm{b}}\end{array}$ & $\mathrm{C}: \mathrm{N}$ & $\begin{array}{c}\mathrm{TSS} \\
{ }^{\circ} \text { Brix }\end{array}$ & $\begin{array}{c}\text { TA \% oxalic } \\
\text { acid }\end{array}$ & $\begin{array}{c}\text { Ripening } \\
\text { index }\end{array}$ \\
\hline Peat & $946 \mathrm{f}$ & $34.65 \mathrm{c}$ & $403.0 \mathrm{ab}$ & $11.65 \mathrm{a}$ & $7.25 \mathrm{a}$ & 0.128 & $58.69 \mathrm{a}$ \\
AmN150 & $2097 \mathrm{~d}$ & $56.85 \mathrm{a}$ & $412.8 \mathrm{a}$ & $7.26 \mathrm{c}$ & $7.23 \mathrm{a}$ & 0.120 & $60.70 \mathrm{a}$ \\
AmN200 & $1799 \mathrm{e}$ & $55.23 \mathrm{a}$ & $390.3 \mathrm{c}$ & $7.07 \mathrm{c}$ & $6.10 \mathrm{~b}$ & 0.113 & $54.21 \mathrm{ab}$ \\
AmN250 & $2031 \mathrm{~d}$ & $55.10 \mathrm{a}$ & $397.5 \mathrm{bc}$ & $7.21 \mathrm{c}$ & $6.83 \mathrm{ab}$ & 0.127 & $54.98 \mathrm{ab}$ \\
CompN150 & $3263 \mathrm{c}$ & $35.78 \mathrm{c}$ & $375.3 \mathrm{~d}$ & $10.50 \mathrm{~b}$ & $6.23 \mathrm{~b}$ & 0.140 & $44.95 \mathrm{c}$ \\
CompN200 & $3984 \mathrm{~b}$ & $47.35 \mathrm{~b}$ & $376.4 \mathrm{~d}$ & $7.96 \mathrm{c}$ & $6.10 \mathrm{~b}$ & 0.114 & $54.32 \mathrm{ab}$ \\
CompN250 & $4203 \mathrm{a}$ & $36.20 \mathrm{c}$ & $376.9 \mathrm{~d}$ & $10.44 \mathrm{~b}$ & $5.95 \mathrm{~b}$ & 0.122 & $48.78 \mathrm{bc}$ \\
\hline Probability & $* * *$ & $* * *$ & $* * *$ & $* * *$ & $*$ & $\mathrm{~ns}$ & $* *$ \\
\hline
\end{tabular}

Note. Values connected by the same letter within a column are not significantly different at $\alpha=0.05 ; *-p<0.05, * *-p<0.01$, *** $-p<0.001 ; \mathrm{ns}-$ non-significant; $\mathrm{D}_{\mathrm{b}}-$ dry biomass.

Table 3. Colorimetric traits: lightness $\left(\mathrm{L}^{*}\right)$, chromacity $\left(\mathrm{C}^{*}\right)$, hue angle $\left(\mathrm{H}^{\circ}\right)$, ascorbic acid $(\mathrm{AA})$, total flavonols and Trolox equivalent antioxidant capacity (TEAC) as affected by different media

\begin{tabular}{ccccccc}
\hline Treatments & $\mathrm{L}^{*}$ & $\mathrm{C}^{*}$ & $\mathrm{H}^{\circ}$ & $\begin{array}{c}\mathrm{AA} \\
\mathrm{mg} 100 \mathrm{~mL}^{-1}\end{array}$ & $\begin{array}{c}\text { Flavonols } \\
\mu \mathrm{g} \mathrm{mL} \mathrm{m}^{-1}\end{array}$ & $\begin{array}{c}\text { TEAC } \\
\mu \mathrm{M} \mathrm{TE} \mathrm{g} \mathrm{F}_{\mathrm{b}}\end{array}$ \\
\hline Peat & $33.68 \mathrm{~b}$ & $14.66 \mathrm{~b}$ & $179.12 \mathrm{a}$ & 137.4 & $40.22 \mathrm{a}$ & $16.36 \mathrm{a}$ \\
AmN150 & $34.19 \mathrm{~b}$ & $15.82 \mathrm{~b}$ & $179.12 \mathrm{a}$ & 147.6 & $39.59 \mathrm{a}$ & $15.88 \mathrm{a}$ \\
AmN200 & $32.94 \mathrm{~b}$ & $14.62 \mathrm{~b}$ & $179.12 \mathrm{a}$ & 126.1 & $34.58 \mathrm{~b}$ & $15.23 \mathrm{a}$ \\
AmN250 & $33.67 \mathrm{~b}$ & $14.78 \mathrm{~b}$ & $179.11 \mathrm{a}$ & 117.8 & $34.89 \mathrm{~b}$ & $13.30 \mathrm{~b}$ \\
CompN150 & $37.37 \mathrm{a}$ & $18.74 \mathrm{a}$ & $179.06 \mathrm{~b}$ & 123.1 & $19.53 \mathrm{c}$ & $10.08 \mathrm{c}$ \\
CompN200 & $37.79 \mathrm{a}$ & $20.15 \mathrm{a}$ & $179.05 \mathrm{~b}$ & 120.7 & $16.74 \mathrm{~d}$ & $8.86 \mathrm{c}$ \\
CompN250 & $37.76 \mathrm{a}$ & $19.11 \mathrm{a}$ & $179.07 \mathrm{~b}$ & 129.0 & $19.02 \mathrm{c}$ & $8.42 \mathrm{c}$ \\
\hline Probability & $* * *$ & $* * *$ & $* *$ & $\mathrm{~ns}$ & $* * *$ & $* * *$ \\
\hline
\end{tabular}

Note. Values connected by the same letter within a column are not significantly different at $\alpha=0.05 ; * *-p<0.01, * * *-p<0.001$; $\mathrm{ns}$ - non-significant; $\mathrm{F}_{\mathrm{b}}$ - fresh biomass. 
showed higher TEAC than those in $\mathrm{NH}_{4} \mathrm{NO}_{3}$ or compost amended media. Thus, spinach cultivation in peat resulted in a $62 \%$ to $94 \%$ higher TEAC than in compost. Similarly, the addition of $\mathrm{NH}_{4} \mathrm{NO}_{3}$ in the media resulted in a $32 \%$ to $89 \%$ higher TEAC than that of compost.

As presented in Table 4, spinach grown in compost amended media produced the maximum $\mathrm{F}_{\mathrm{b}}$, $\mathrm{D}_{\mathrm{b}}$ and $\mathrm{LMC}$, whereas peat treated plants produced the minimum. However, peat medium resulted in the highest $\mathrm{D}_{\mathrm{m}}$ ( $\mathrm{mg} \mathrm{g}^{-1}$ fresh biomass), whereas compost in the least $\mathrm{D}_{\mathrm{m}}$.

The statistical correlations between physical, morphological and biochemical quality attributes revealed the linkage between various quality attributes. $\mathrm{NO}_{3}$ was found to be negatively correlated with TOC, TSS, $\mathrm{H}^{\circ}$, flavonols, TEAC and $\mathrm{D}_{\mathrm{m}}$, although the relation with TSS was weak. Further, positive correlations of $\mathrm{NO}_{3}$ with $\mathrm{C}^{*}, \mathrm{~F}_{\mathrm{b}}$ and $\mathrm{D}_{\mathrm{b}}$ were evident (Table 5).

Moreover, TOC was found to be positively linked with TSS, and $\mathrm{H}^{\circ}$, whereas negatively linked with $\mathrm{C}^{*}$, flavonols, TEAC, $\mathrm{F}_{\mathrm{b}}$ and $\mathrm{D}_{\mathrm{b}} . \mathrm{H}^{\circ}$ was positively related with flavonols, TEAC and $\mathrm{D}_{\mathrm{m}}$, and negatively with $\mathrm{F}_{\mathrm{b}}$ and $\mathrm{D}_{\mathrm{b}}$. A positive correlation between flavonols, TEAC and $\mathrm{D}_{\mathrm{m}}$ was also evident, whereas both flavonols and TEAC were found to be negatively correlated with $\mathrm{C}^{*}, \mathrm{~F}_{\mathrm{b}}$ and $\mathrm{D}_{\mathrm{b}}$ (Table 5).

Table 4. Comparison of means for fresh biomass $\left(\mathrm{F}_{\mathrm{b}}\right)$, dry biomass $\left(\mathrm{D}_{\mathrm{b}}\right)$, dry matter $\left(\mathrm{D}_{\mathrm{m}}\right)$ and leaf moisture content (LMC) affected by different media

\begin{tabular}{ccccc}
\hline Treatments & $\begin{array}{c}\mathrm{F}_{\mathrm{b}} \\
\mathrm{g}\end{array}$ & $\begin{array}{c}\mathrm{D}_{\mathrm{b}} \\
\mathrm{g}\end{array}$ & $\begin{array}{c}\mathrm{D}_{\mathrm{m}} \\
\mathrm{mg} \mathrm{g}^{-1} \mathrm{~F}_{\mathrm{b}}\end{array}$ & $\begin{array}{c}\text { LMC } \\
\%\end{array}$ \\
\hline Peat & $91.45 \mathrm{~b}$ & $11.89 \mathrm{~d}$ & $131.90 \mathrm{a}$ & $86.81 \mathrm{~d}$ \\
AmN150 & $111.36 \mathrm{~b}$ & $13.44 \mathrm{~cd}$ & $124.10 \mathrm{ab}$ & $87.59 \mathrm{~cd}$ \\
AmN200 & $129.78 \mathrm{~b}$ & $15.21 \mathrm{abcd}$ & $116.70 \mathrm{abc}$ & $88.33 \mathrm{bcd}$ \\
AmN250 & $126.63 \mathrm{~b}$ & $13.56 \mathrm{bcd}$ & $109.90 \mathrm{bcd}$ & $89.01 \mathrm{abc}$ \\
CompN150 & $176.67 \mathrm{a}$ & $18.52 \mathrm{a}$ & $104.20 \mathrm{~cd}$ & $89.58 \mathrm{ab}$ \\
CompN200 & $178.92 \mathrm{a}$ & $17.34 \mathrm{abc}$ & $97.38 \mathrm{~d}$ & $90.26 \mathrm{a}$ \\
CompN250 & $189.64 \mathrm{a}$ & $17.46 \mathrm{ab}$ & $92.81 \mathrm{~d}$ & $90.72 \mathrm{a}$ \\
\hline Probability & $* * *$ & $* *$ & $* *$ & $* *$
\end{tabular}

Note. Values connected by the same letter within a column are not significantly different at $\alpha=0.05 ; * *-p<0.01$, $* * *-p<0.001$.

Table 5. Pearson's coefficient of correlations between nitrate $\left(\mathrm{NO}_{3}\right)$ content, total nitrogen (TN), total organic carbon (TOC), total soluble solids (TSS), hue angle $\left(\mathrm{H}^{\circ}\right)$, total flavonols, Trolox equivalent antioxidant capacity (TEAC), fresh biomass $\left(\mathrm{F}_{\mathrm{b}}\right)$, dry biomass $\left(\mathrm{D}_{\mathrm{b}}\right)$, dry matter $\mathrm{mg} \mathrm{g}^{-1} \mathrm{~F}_{\mathrm{b}}\left(\mathrm{D}_{\mathrm{m}}\right)$

\begin{tabular}{|c|c|c|c|c|c|c|c|c|c|}
\hline & $\mathrm{NO}_{3}$ & $\mathrm{TN}$ & TOC & TSS & $\mathrm{H}^{\circ}$ & Flavonols & TEAC & $\mathrm{F}_{\mathrm{b}}$ & $\mathrm{D}_{\mathrm{b}}$ \\
\hline $\mathrm{NO}_{3}$ & - & & & & & & & & \\
\hline $\mathrm{TN}$ & $\mathrm{ns}$ & - & & & & & & & \\
\hline TOC & $-0.74 * *$ & $0.42 *$ & - & & & & & & \\
\hline TSS & $-0.49 * *$ & $\mathrm{~ns}$ & $0.49 * *$ & - & & & & & \\
\hline $\mathrm{H}^{\circ}$ & $-0.67^{* *}$ & $\mathrm{~ns}$ & $0.70^{* *}$ & $\mathrm{~ns}$ & - & & & & \\
\hline Flavonols & $-0.92 * *$ & $0.41^{*}$ & $-0.76^{* *}$ & $0.49^{* *}$ & $0.73 * *$ & - & & & \\
\hline TEAC & $-0.78^{* *}$ & $0.66^{* *}$ & $-0.79 * *$ & $0.53 * *$ & $0.72 * *$ & $0.83 * *$ & - & & \\
\hline $\mathrm{F}_{\mathrm{b}}$ & $0.77 * *$ & ns & $-0.67 * *$ & $-0.78 * *$ & $-0.70 * *$ & $-0.77 * *$ & $-0.73 * *$ & - & \\
\hline $\mathrm{D}_{\mathrm{b}}$ & $0.63 * *$ & ns & $-0.55^{* *}$ & $-0.45^{*}$ & $-0.46^{*}$ & $-0.68 * *$ & $-0.57 * *$ & $0.63 * *$ & - \\
\hline $\mathrm{D}_{\mathrm{m}}$ & $-0.73^{* *}$ & ns & $0.57^{* *}$ & $0.65^{* *}$ & $0.60 * *$ & $0.67^{* *}$ & $0.58^{* *}$ & $-0.78^{* *}$ & $-0.55^{* *}$ \\
\hline
\end{tabular}

$*-p<0.05, * *-p<0.01 ; \mathrm{ns}-$ non-significant at $\alpha=0.05$

\section{Discussion}

Salt accumulation in the media was monitored during the growth of spinach. Low electrical conductivity (EC) of all the media ( 0.22 to $\left.0.42 \mathrm{mS} \mathrm{cm}^{-2}\right)$ at harvest stage suggests less salt accumulation and efficient nutrients uptake by the plants. The $\mathrm{pH}$ of compost amended media reached at 8.0 at harvest, whereas a good $\mathrm{pH}$ range for plant growth (6.2 to 6.7$)$ was maintained by peat and
$\mathrm{NH}_{4} \mathrm{NO}_{3}$ fertigated media. Therefore, these media may be reused due to less salt accumulation and optimum $\mathrm{pH}$ value. In the present study, TN in plants grown in peat or compost additions was lower than in $\mathrm{NH}_{4} \mathrm{NO}_{3}$ fertigated plants, mainly due to the fact that $\mathrm{N}$ content per leaf area increases with the $\mathrm{N}$ availability (Noguchi, Terashima, 2006), and low N nutrition levels decrease $\mathrm{N}$ content of plant shoot and root (Watanabe et al., 2010). 
Compost additions resulted in a higher $\mathrm{NO}_{3}$ accumulation in spinach. In general, organically grown crops accumulate less nitrate content but active mineralization of organic matter could lead to excessive $\mathrm{NO}_{3}$ accumulation in plants (Anjana et al., 2007). Moreover, the combination of $\mathrm{NO}_{3}$ and $\mathrm{NH}_{4}^{+}$ in a fertilizer reduces the nitrate content in vegetables (Wang et al., 2009). TOC and TSS were higher in plants grown in peat and $\mathrm{NH}_{4} \mathrm{NO}_{3}$ additions. In general, soluble organic compounds such as soluble sugars and organic acids serve as osmoticums to maintain osmotic potential and generate turgor pressure but at specific conditions, $\mathrm{NO}_{3}$ in cell vacuoles could also serve as an alternative to organic osmoticums (Burns et al., 2011).

$\mathrm{NO}_{3}$ was positively linked to fresh and dry biomass which indicates that $\mathrm{NO}_{3}$ was reduced to ammonium that was assimilated into amino acids (Masclaux-Daubresse et al., 2010), producing more protein and thus resulting in more biomass. Crop demand for $\mathrm{N}$ is also dependent on dry matter accumulation and therefore vegetables such as lettuce shows increase in fresh and dry biomass with the increase in $\mathrm{NO}_{3}$ application and its accumulation in the leaves (Cometti et al., 2011). A correlation between TOC, TSS and $\mathrm{D}_{\mathrm{m}}$ suggests an increase in carbon assimilation which then boosts the production of carbohydrates and plant biomass. Leaf chlorophyll is directly related to $\mathrm{TN}$ in a leaf as nitrogen is one of the basic components of chlorophyll structure. In the present study, significantly higher $\mathrm{H}^{\circ}$ affirmed the higher content of chlorophyll in peat and $\mathrm{NH}_{4} \mathrm{NO}_{3}$ treatments that led to increased $\mathrm{CO}_{2}$ fixation and thus resulting in higher TOC in these treatments (Table 2). Spinach grown in compost additions had higher leaf clarity or lightness (see L* value in Table 4) and higher $\mathrm{C}^{*}$ values indicating vividness in leaf colour. This was also obvious from relatively lower $\mathrm{H}^{\circ}$ (more yellow aspect), as yellowish hue has more lightness and is more vivid compared to greener hue $\left(\mathrm{H}^{\circ}\right.$ close to $\left.180^{\circ}\right)$. Besides, positive relation of $\mathrm{H}^{\circ}$ with TOC and $\mathrm{D}_{\mathrm{m}}$ was present, owing to the increase in carbohydrates and proteins in high chlorophyll containing plants, consequently adding to the solid contents of the cells.

In fruits and vegetables, the concentration and type of sugars and organic acids, and the balance between them decisively contribute to the product flavour (Bayyari, Costell, 2010). Ripening index of plants grown in peat and $\mathrm{NH}_{4} \mathrm{NO}_{3}$ media was highest and moreover, these media produced the highest vitamin $\mathrm{C}, \mathrm{TOC}, \mathrm{TSS}$, total flavonols and TEAC in spinach, all adding to the nutritional value of spinach. In spinach, flavonols and their derivatives are found to be the main flavonoids (Cho et al., 2008). The carbon nutrient balance predicts that the availability of excess carbon at a certain nutrient level leads to the increased production of carbon based secondary metabolites and their precursors (Ibrahim et al. 2011). However, contrary to high flavonols concentrations, plants grown in peat and $\mathrm{NH}_{4} \mathrm{NO}_{3}$ additions produced less $\mathrm{F}_{\mathrm{b}}$ and $\mathrm{D}_{\mathrm{b}}$ because biomass production is negatively correlated to phenolic components due to the competition between protein synthesis and secondary metabolite production (Anjana et al., 2007; Ibrahim et al., 2012).

\section{Conclusion}

Modification in the open soilless culture technique proved efficient in utilizating the resources. First, use of soilless media, controlled $\mathrm{NH}_{4} \mathrm{NO}_{3}$ fertigation, scheduled and quantified sprinkler irrigation not only led to negligible emission but also sustained the salts and $\mathrm{pH}$ in media to almost optimum levels during growth period. Consequently, contamination in the soil was less, spinach yield was higher and the media remained reusable for growing the crop in next season.

As to spinach quality, the peat moss and $\mathrm{NH}_{4} \mathrm{NO}_{3}$ fertigation resulted in the accumulation of lower amounts of $\mathrm{NO}_{3}$ and more organic carbon that resulted in more dry matter. Higher total soluble solids contents and higher ripening indices were also observed. This was accompanied by higher chlorophyll contents $\left(\mathrm{H}^{\circ}\right.$ close to 180), higher flavonoids and higher antioxidant activity, which are attributes of a high quality food product. So, for producing good quality spinach, growing media consisting of sphagnum peat moss in combination with $\mathrm{NH}_{4} \mathrm{NO}_{3}$ application could be used according to the suggested modified open soilless culture technique.

Received 29092014 Accepted 06032015

\section{References}

Anjana, Umar S., Iqbal M. 2007. Nitrate accumulation in plants, factors affecting the process, and human health implications: a review. Agronomy for Sustainable Development, 27: 45-57 http://dx.doi.org/10.1051/agro:2006021

Bayyari S., Costell E. 2010. Sensory evaluation of fruit and vegetable flavors. Hui Y. H. (ed.). Handbook of fruit and vegetable flavors, p. 47-58

Brand-Williams W., Cuvelier M. E., Berset C. 1995. Use of a free radical method to evaluate antioxidant activity. LWTFood Science and Technology, 28: 25-30 http://dx.doi.org/10.1016/S0023-6438(95)80008-5

Burns I. G., Durnford J., Lynn J., Mcclement S., Hand P., Pink D. 2011. The influence of genetic variation and nitrogen source on nitrate accumulation and iso-osmotic regulation by lettuce. Plant and Soil, 352: 321-339 http://dx.doi.org/10.1007/s11104-011-0999-0

Cho M. J., Howard L. R., Prior R. L., Morelock T. 2008. Flavonoid content and antioxidant capacity of spinach genotypes determined by high-performance liquid chromatography/mass spectrometry. Journal of the Science of Food and Agriculture, 88: 1099-1106 http://dx.doi.org/10.1002/jsfa.3206

Cometti N., Martins M., Bremenkamp C., Nunes J. 2011. Nitrate concentration in lettuce leaves depending on photosynthetic photon flux and nitrate concentration in the nutrient solution. Horticultura Brasileira, 29: 548-553 http://dx.doi.org/10.1590/S0102-05362011000400018 
Crisosto C., Valero C., Slaughter D. 2007. Predicting pitting damage during processing in California clingstone peaches using color and firmness measurements. Applied Engineering in Agriculture, 23: 2-6 http://dx.doi.org/10.13031/2013.22598

Ergun M., Jezik K. M. 2011. Measuring electrochemical fruit quality of refrigerated 'Hanita' plum by Bioelectric Vincent method. Zemdirbyste-Agriculture, 98 (3): 315-322

Gajewski M., Radzanowska J., Danilcenko H., Jariene E., Cerniauskiene J. 2008. Quality of pumpkin cultivars in relation to sensory characteristics. Notulae Botanicae Horti Agrobotanici Cluj-Napoca, 36 (1): 73-79

Gruda N. 2009. Do soilless culture systems have an influence on product quality of vegetables? Journal of Applied Botany and Food Quality, 82: 141-147

Ibrahim M. H., Jaafar H. Z. E., Rahmat A., Rahman Z. A. 2011. The relationship between phenolics and flavonoids production with total non structural carbohydrate and photosynthetic rate in Labisia pumila Benth. under high $\mathrm{CO}$, and nitrogen fertilization. Molecules, 16 (1): 162-174 http://dx.doi.org/10.3390/molecules 16010162

Ibrahim M. H., Jaafar H. Z. E., Rahmat A., Rahman Z. A. 2012. Involvement of nitrogen on flavonoids, glutathione, anthocyanin, ascorbic acid and antioxidant activities of Malaysian medicinal plant Labisia pumila Blume (Kacip Fatimah). International Journal of Molecular Sciences, 13 (1): 393-408

León A., Viña S., Frezza D., Chaves A., Chiesa A. 2007. Estimation of chlorophyll contents by correlations between SPAD-502 meter and chroma meter in butterhead lettuce. Communications in Soil Science and Plant Analysis, 38: 2877-2885 http://dx.doi.org/10.1080/00103620701663115

Liang Z., Sang M., Fan P., Wu B., Wang L., Yang S., Li S. 2011. CIELAB coordinates in response to berry skin anthocyanins and their composition in Vitis. Journal of Food Science, 76 (3): C490-497 http://dx.doi.org/10.1111/j.1750-3841.2011.02095.x

Mahmood T., Anwar F., Abbas M., Boyce M. C., Saari N. 2012. Compositional variation in sugars and organic acids at different maturity stages in selected small fruits from Pakistan. International Journal of Molecular Sciences, 13: $1380-1392$ http://dx.doi.org/10.3390/ijms13021380

Masclaux-Daubresse C., Daniel-Vedele F., Dechorgnat J., Chardon F., Gaufichon L., Suzuki A. 2010. Nitrogen uptake, assimilation and remobilization in plants: challenges for sustainable and productive agriculture. Annals of Botany, 105: $1141-1157$

http://dx.doi.org/10.1093/aob/mcq028

Noguchi K., Terashima I. 2006. Responses of spinach leaf mitochondria to low $\mathrm{N}$ availability. Plant, Cell and Environment, 29: 710-719 http://dx.doi.org/10.1111/j.1365-3040.2005.01457.x

Orsini F., Kahane R., Nono-Womdim R., Gianquinto G. 2013. Urban agriculture in the developing world: a review. Agronomy for Sustainable Development, 33: 695-720 http://dx.doi.org/10.1007/s13593-013-0143-z

Osmani S. A., Hansen H. E., Malien-Aubert C., Olsen C. E., Bak S., Møller B. L. 2009. Effect of glucuronosylation on anthocyanin color stability. Journal of Agricultural and Food Chemistry, 57: 3149-3155 http://dx.doi.org/10.1021/jf8034435
Ren H., Endo H., Hayashi T. 2001. Antioxidative and antimutagenic activities and polyphenol content of pesticide-free and organically cultivated green vegetables using water-soluble chitosan as a soil modifier and leaf surface spray. Journal of the Science of Food and Agriculture, 81: 1426-1432 http://dx.doi.org/10.1002/jsfa.955

Ruck J. A. 1961. Chemical methods for analysis of fruit and vegetable products. Ottava, Canada

Schmidhalter U. 2005. Development of a quick on-farm test to determine nitrate levels in soil. Journal of Plant Nutrition and Soil Science, 168: 432-438 http://dx.doi.org/10.1002/jpln.200520521

Siomos A. S., Beis G., Papadopoulu P. P., Barbayiannis N. 2001. Quality and composition of lettuce (cv. Plenty) grown in soil and soilless culture. Acta Horticulturae, 548: 445-450

Tabatabaei S. J., Yusefi M., Hajiloo J. 2008. Effects of shading and $\mathrm{NO}_{3}: \mathrm{NH}_{4}$ ratio on the yield, quality and $\mathrm{N}$ metabolism in strawberry. Scientia Horticulturae, 116: 264-272 http://dx.doi.org/10.1016/j.scienta.2007.12.008

Van Os E. A., van Weel P. A., Bruins M. A., Wilms J. A. M., de Haan J. J., Verhoeven J. 2012. System development for outdoor soilless production of leek (Allium porrum). Acta Horticulturae, 947: 139-146

Wang J., Zhou Y., Dong C., Shen Q., Putheti R. 2009. Effects of $\mathrm{NH}_{4}{ }^{+}-\mathrm{N} / \mathrm{NO}_{3}-\mathrm{N}$ ratios on growth, nitrate uptake and organic acid levels of spinach (Spinacia oleracea L.). African Journal of Biotechnology, 8: 3597-3602

Wang S. Y., Lin S. S. 2002. Compost as soil supplement enhanced plant growth and fruit quality of strawberry. Journal of Plant Nutrition, 25: 2243-2259 http://dx.doi.org/10.1081/PLN-120014073

Wang Y. T., Huang S. W., Liu R. L., Jin J. Y. 2007. Effects of nitrogen application on flavor compounds of cherry tomato fruits. Journal of Plant Nutrition and Soil Science, 170: $461-468$ http://dx.doi.org/10.1002/jpln.200700011

Watanabe C. K., Hachiya T., Takahara K., Kawai-Yamada M., Uchimiya H., Uesono Y., Terashima I., Noguchi K. 2010. Effects of AOX1a deficiency on plant growth, gene expression of respiratory components and metabolic profile under low-nitrogen stress in Arabidopsis thaliana. Plant and Cell Physiology, 51 (5): 810-822 http://dx.doi.org/10.1093/pcp/pcq033 
ISSN 1392-3196 / e-ISSN 2335-8947

Zemdirbyste-Agriculture, vol. 102, No. 2 (2015), p. 201-208

DOI 10.13080/z-a.2015.102.026

\title{
Špinatụ smulkioji daržininkystė: auginimas atviroje, be dirvožemio sistemoje
}

\author{
S. Ejaz ${ }^{1,2}$, K. M. Jezik ${ }^{1}$, W. Stumpf ${ }^{1}$, C. Gosch ${ }^{3}$, H. Halbwirth ${ }^{3}$, K. Stich \\ ${ }^{1}$ Gamtos išteklių ir gyvybès mokslų universitetas, Austrija \\ ${ }^{2}$ Bahauddin Zakariya universitetas, Pakistanas \\ ${ }^{3}$ Technologijos universiteto Cheminès inžinerijos institutas, Austrija
}

\section{Santrauka}

Tyrimo tikslas - sukurti atvirą, be dirvožemio, augalų auginimo sistemą, pasižyminčią dideliu vandens ir maisto medžiagų naudojimo efektyvumu ir maža emisija i aplinką, geros kokybės špinatams auginti smulkiosios daržininkystès būdu. Daržiniai špinatai buvo auginami talpyklose terpèje be dirvožemio, papildyta organiniais ir neorganiniais mitybos šaltiniais. Bandymai buvo išdėstyti randomizuotai, keturi pakartojimai. Vertintos septynios auginimo terpès: baltosios durpinès samanos, baltosios durpinès samanos su 150, 200 ir 250 ppm amonio nitrato $\left(\mathrm{NH}_{4} \mathrm{NO}_{3}\right)$ ir baltosios durpinès samanos, papildytos kompostu, turinčiu šioms $\mathrm{NH}_{4} \mathrm{NO}_{3}$ koncentracijoms ekvivalentišką kiekį azoto. Siekiant sumažinti vandens emisiją ị aplinką, drèkinta pagal schemą ir joje numatytas dozes, naudojant purkštuvus. Visą auginimo laikotarpị matuota druskos kaupimasis ir terpių pH. Špinatų lapuose analizuotas bendras tirpių kietujų medžiagų kiekis, titruojamasis rūgštumas, subrendimo indeksas, bendras azoto kiekis, bendras organinès anglies kiekis, anglies ir azoto santykis, žalios biomasès kiekis, sausos biomasès kiekis, sausųų medžiagų kiekis ( $\mathrm{mg} \mathrm{g}^{-1}$ žalios masės), lapų drègmės kiekis, nitratų kiekis, kolorimetrinès savybės (šviesumas, spalvingumas ir atspalvio kampas), askorbo rūgšties kiekis, bendras flavonolių bei antocianinų kiekis ir antioksidacinis aktyvumas. Iš visų terpių baltųjų durpių samanų su $\mathrm{NH}_{4} \mathrm{NO}_{3}$ variante augalai turejjo mažiau nitratų, daugiau organinès anglies ir sausujų medžiagų ( $\mathrm{mg} \mathrm{g}^{-1}$ žalios masès), didesnị bendrą tirpių kietụjų medžiagų kiekị ir subrendimo indeksą. Didesnis flavonoidų kiekis ir antioksidacinis aktyvumas taip pat nustatytas augaluose, augintuose šiose terpèse. Be to, šios terpès sukaupė mažiau druskų ir išlaikė optimalų špinatams auginti pH lygị.

Reikšminiai žodžiai: agroteršalai, augalų auginimas be dirvožemio, durpinès samanos, Spinacia oleracea, ūkininkavimas mieste. 